KINGA MARULEWSKA

Instytut Politologii UMK

\title{
IDEA „WIECZNEGO POKOJU” KANTA A WSPÓLCZESNY PORZĄDEK MIĘDZYNARODOWY
}

\author{
„Sama broń nie wystarcza, \\ by utrzymać w świecie pokój. \\ Najważniejsi są ludzie" \\ John F. Kennedy
}

\begin{abstract}
$\mathrm{H}$ istoria dostarcza nam wielu przykładów na to, w jaki sposób wojna wpływa na losy poszczególnych ludzi, na porządek międzynarodowy, jakie piętno odciska na ludzkości. Kiedyś uważano ja za ogień, w którym wypala się to, co nietrwałe i słabe, by zostało tylko to, co najsilniejsze. W czasach Kanta, wojnę postrzegano jako dopełnienie pokoju, występujące $\mathrm{z}$ nim zamiennie po to, by nie doprowadzić do upadku społeczeństwa, lecz by podtrzymać w nim męstwo, honor i odwagę. Również Kant opisał wojnę jako znaczący moment w historii narodów i określił jako coś wzniosłego. Nie stoi to w sprzeczności z projektem filozoficznym Do wiecznego pokoju. Współcześnie wojna jest najgorszą tragedia, jaka może się wydarzyć. Jest ona obecnie zaprzeczeniem nie tylko pokoju, ale również wszystkiego, co wartościowe, czyli życia, zdrowia, zgody, dobrobytu.

Rozprawka Zum emigen Frieden została opublikowana przez Kanta w 1795 roku „na targi na Michała”1 czyli około 4 października. Najżywiej odebrano jej przesłanie wśród Polaków i Francuzów, którzy odnosili ją do swej aktualnej sytuacji: jedni do zaboru prusko-austriackorosyjskiego, a drudzy do czasów rewolucji francuskiej. Interesujący jest wplyw Do wiecznego pokoju na ziemiach polskich.
\end{abstract}

${ }^{1}$ H. F. Klemme, Do wiecznego pokoju, w: I. Kant, O porzekeadle..., Do wiecznego pokoju, Toruń 1995, s. LV. 
E. Petzold zauważa w swym artykule, iż ,fakt ciekawy, że z pism Kanta pierwszy doczekał się przekładu polskiego Projekt filozoficzny w sprawie pokoju wiecaystego"2. Mowa jest tutaj o pierwszych dwóch tłumaczeniach na język polski Do wiecznego pokoju. Pierwszy, anonimowy przekład z języka niemieckiego był najprawdopodobniej autorstwa J. Bychowca $^{3}$. Data wydania tego przekładu nie jest jednoznaczna $\mathrm{i}$ w różnych źródłach podawane sa różne wersje. Według S. Harasska przekład ten ukazał się już w rok po wydaniu wersji oryginalnej, jednakże J. Bychowiec dopiero w latach 1799-1802 przebywał w Królewcu, gdzie pobierał nauki u Kanta. Wnioskować z tego można, że mniej więcej w tych latach powinien się był ukazać tenże przekład, co dodatkowo potwierdzaja Encyklopedia powszechna T. Glückberga oraz list J. Bychowca do J. I. Kraszewskiego. Jednak do naszych czasów nie zachował się ani jeden egzemplarz tego przekładu, co mogło być spowodowane albo brakiem pieniędzy na wydanie, albo rozprowadzeniem bardzo małego nakładu tak, że nie dotrwał on do naszych czasów. Drugiego przekładu, tym razem z języka francuskiego, dokonał nieco później pijar polski Szymon Bielski.

Dlaczego akurat Do wiecznego pokoju doczekało się jako pierwsze z dzieł Kanta tłumaczenia i to na dodatek niedługo po ukazaniu się wersji oryginalnej? Odpowiedź jest dość prosta według S. Harasska, który zauważa, że w piśmie Kanta „mogli Polacy (...) wyczytać pośrednia zachętę do walki o wolność" i że "te właśnie względy pobudzily Bychowca i Bielskiego do podjęcia trudu około przełożenia (...), jest rzeczą bardzo możliwą" Tak więc motywacją do przełożenia niezbyt obszernego dziełka mógł być jego związek ze współczesnymi filozofowi wydarzeniami. E. Petzold stwierdza zaś, że „Projekt zawiera jeszcze wiele miejsc, przy których pisaniu autor niezawodnie myślał o Polsce" ${ }^{\text {. }}$. Co więcej, w Religii w obrębie samego rozumu wydanej już w 1793 r. pisze Kant: „nie protestuję przeciwko temu, że ci, którzy sprawują władzę, zmuszeni przez bieżące okoliczności, odsuwają na później, wciąż na później zrzucenie tych trzech [rodzajów] kajdan"”. Niejasne jest, o jakie kajdany

\footnotetext{
2 E. Petzold, Kanta „W sprawie Pokoju wieçystego. Projekt filozoficzny” a Polska, w: Pamiętnik Lwowski, Lwów 1903, s. 601.

${ }^{3}$ M. Żelazny, Bibliographie der polnischen Übersetzungen der Schriften von Immanuel Kant bis 1996, w: D. Pakalski, M. Żelazny, Polnische Kant- Übersetæungen, w: Kant-Studien 89. Jahrg. (Sonderdruck), Berlin 1998, s. 122.

${ }^{4}$ S. Harassek, Kant w Polsce przed rokiem 1830, Kraków 1916, s. 56.

5 Tamże, s. 57.

${ }^{6}$ E. Petzold, dz. cyt., s. 603.

${ }^{7}$ I. Kant, Religia w obrębie samego rozumu, Kraków 1993, s. 226-227.
} 
Idea ,wiec₹nego pokoju” Kanta... 175

(trzech zaborców?) dokładnie chodzi. Pewne jest jednak, że I. Kant w tej samej rozprawie powołuje się na konieczność respektowania moralnych praw do samostanowienia państwa.

Projekt filozoficzny Kanta został na ziemiach polskich odebrany dość jednoznacznie jako potępienie okupantów, którzy zignorowali suwerenność państwa polskiego, najpierw naruszając terytorium państwa polskiego poprzez dwa pierwsze rozbiory, a później pozbawiając naród polski państwowości. Przytaczano tutaj zwłaszcza piąty artykuł preliminarny - „żadne państwo nie powinno mieszać się przemocą do ustroju i rządów innego państwa"s. Niewielka odległość pomiędzy Królewcem, a ziemiami polskimi pozwala przypuszczać, że Do wiecznego pokoju istotnie jest głosem w sprawie polskiej. Krytyczny stosunek Kanta do zaborów wydają się potwierdzać inne fragmenty jego pism, chociaż nie jest to jednoznaczne $z$ bezkrytycznym spojrzeniem na sam naród polski. Jak pisze Kant, „Polska to szczególny kraj”, nie skapiąc słów krytyki pod adresem Polaków, którzy są może nieszczęśliwi, ale na pewno nie niewinni ${ }^{10}$.

W taki właśnie sposób interpretowano znaczenie Do wiecznego pokoju za czasów Kanta. Projekt filozoficzny miał jednak, prócz skomentowania i skrytykowania ówczesnej sytuacji międzynarodowej, również inne zadanie. Można powiedzieć, że sa to zalecenia, które z założenia nie miały tracić na aktualności w odniesieniu do międzynarodowego porządku, lecz powinny być filozoficznym przepisem na to, jak doprowadzić do pokoju, który już nigdy nie miał być przerwany wojną.

Projekt filozoficzny Do wiecz̨nego pokoju składa się dwóch rozdziałów oraz dwóch dopisków. W pierwszym rozdziale opisanych jest sześć artykułów preliminarnych, czyli wstępnych albo raczej przedwstępnych. Preliminariami pokojowymi nazywano umowę pomiędzy wojującymi państwami, w której strony sporu przyrzekały zawrzeć traktat pokojowy albo przywracały pokój, pozostawiając kwestie szczegółowe do uregulowania w późniejszej umowie. Słowo „preliminarne” nie jest tutaj określeniem przypadkowym, lecz zwraca uwage na to, co jest cechą artykułów tego rozdziału: są to wstępne założenia, które mają dopiero

8 Tenże, Wieczny pokój, Torun 1992, s. 21.

9 Die philosophischen Hauptvorlesungen Immanuel Kant hrsg. Von Arnold Kowalewski, München und Leipzig 1924, s. 357-358; cyt. za: M. Żelazny, Præ̧edmowa tłumacza, w: I. Kant, O porzekadle..., Do wiecznego pokoju, Toruń 1995, s. 12.

${ }_{10}$ M. Żelazny, Przedmowa ttumacza, w: I. Kant, O porzekadle..., Do wiecznego pokoju, Toruń 1995, s. 9. 
przygotować do dalszych tez regulujących szczegółowo kwestię wiecznego pokoju.

Artykuł pierwszy, pierwszego rozdziału w brzmieniu ,żaden traktat pokojowy, w którym przez utajone zastrzeżenie zawarte zostało zarzewie przyszłe wojny, nie może być za takowy uznany" "11, został zakwalifikowany przez Kanta jako prawo zakazu z punktu widzenia władców, ale, co ważniejsze, określony jako artykuł, który wymaga na rządzących natychmiastowego spełnienia. Wydaje się, że jest to celowe i słuszne, ponieważ idealny stan wiecznego pokoju nie nastapi nigdy, jeśli wszelkie traktaty pokojowe będą zaledwie chwilą odpoczynku i regeneracji sił do dalszej wojny, możliwością zwerbowania większej ilości ochotników i produkcji broni. Co więcej, traktat pokojowy, w którym jedna ze stron wyczuwałaby przyszłe zagrożenie, zniszczyłby tę minimalną ilość zaufania, potrzebną do zawieszenia broni, a później do zawarcia pokoju.

Współcześnie nie da się określić, który z zawartych traktatów pokojowych ma ukrytą myśl o rozpoczęciu wojny. Należy się dzisiejszym traktatom pokojowym przypatrywać z ufnością, wierząc w szczerość przystępujących do ugody państw i bacząc na to, że żaden traktat pokojowy, który uznamy za niepewny, nie daje gwarancji pokoju. Dopiero po latach da się określić prawdziwe zamiary układających się stron i ich dalekosiężne plany. Przykładem układów, które miały w sobie zarzewie przyszłej wojny moga być dwustronne układy zawarte w dwudziestoleciu międzywojennym pomiędzy Polską, Związkiem Radzieckim oraz Rzeszą Niemiecka. 25 lipca 1932 r. doszło w Moskwie do podpisania polsko-radzieckiego paktu o nieagresji, który nawiązywał do traktatu ryskiego, paktu Brianda-Kellogga i protokołu Litwinowa, a w swych założeniach przewidywał wyrzeczenie się wojny i wstrzymanie się od uczestnictwa w układach, które byłyby skierowane przeciwko drugiej stronie. Pakt ten zawarto na okres trzech lat. W 1934 roku przedłużono go na okres dziesięciu lat, czyli aż do 1944 r. Również w 1934 r. podpisano polsko-niemiecką deklarację o niestosowaniu przemocy we wzajemnych stosunkach. Jednakże traktaty te były zaledwie opóźnieniem wybuchu wojny, która miała przynieść wymierne korzyści zarówno ZSRR jak i III Rzeszy. Intencje układających się z Polską stron wyraźnie zaprezentowano $\mathrm{w}$ tajnym protokole do paktu o nieagresji między Niemcami a Związkiem Radzieckim z 23 sierpnia 1939 r., który stanowił, że „na wypadek terytorialno-politycznego przekształcenia terytoriów należących do państwa polskiego, sfery interesów Niemiec i ZSRR będa

${ }^{11}$ I. Kant, O porzekeadle... Do wiecznego pokoju, dz. cyt., s. 49. 
Idea ,wiecznego pokoju” Kanta... 177

rozgraniczone przez linię Narew - Wisła - San. Kwestia, czy w interesie obu stron uznane będzie za pożądane utrzymanie niepodległego państwa polskiego, zostanie definitywnie zdecydowana dopiero w ciagu dalszego rozwoju wypadków politycznych"12. Mimo obowiązujących traktatów pokojowych państwa ościenne szykowały się do aneksji terytoriów Polski, która nazwano później „czwartym rozbiorem Polski”. Był to przykład pogwałcenia zawartych wcześniej traktatów pokojowych.

Drugi artykuł preliminarny stanowiący, że ,żadne samoistne państwo (małe czy też duże, to rzecz obojętna) nie może być nabyte przez jakieś inne państwo drogą spadku, zamiany, kupna lub darowizny"13, można uzasadnić wskazując, że państwo nie jest rzeczą, ale, w rozumieniu politologicznym, sformalizowanym społeczeństwem, a więc kupno państwa wiązałoby się z zakupem również ludzi mieszkających na tym terytorium, co przecież jest niewolnictwem i żadnym sposobem nie może być dozwolone. Społeczeństwo ludzi wolnych mieszkających w granicach danego państwa musi mieć prawo decydowania o sobie, a już zwłaszcza o tak ważnych kwestiach jak wcielenie do innego organizmu państwowego, czego, jak wierzę, żadne $\mathrm{z}$ nich by nie chciało. We współczesnym świecie nie znajdujemy przykładów takich działań, chociaż niegdyś były one możliwe, żeby podać za przykład choćby zakup Alaski przez Stany Zjednoczone. W rozumieniu Kanta, przeciwne założeniom wiecznego pokoju jest również dziedziczenie tronu. W Konstytucji 3 Maja znajduje się zapis o powrocie do tradycyjnego dziedziczenia tronu sprzed czasów królów elekcyjnych - „Doznane klęski bezkrólewiów, periodycznie rząd wywracających, powinność ubezpieczenia losu każdego mieszkańca ziemi polskiej, i zamkniecie na zawsze drogi wpływom mocarstw zagranicznych, pamięć świetności i szczęścia Ojczyzny naszej za czasów familii ciagle panujących, potrzeba odwrócenia od ambicji tronu obcych, i możnych Polaków zwrócenia do jednomyślnego wolności narodowej pielęgnowania, wskazały roztropności naszej oddanie tronu Polskiego prawem następstwa" ${ }^{\prime 14}$. Było to spowodowane skojarzeniem wszystkiego, co złe w państwie polskim z okresem królów elekcyjnych, co oczywiście było przejaskrawieniem, ale nie bez ziarenka prawdy. Pomysł powrotu do dziedziczenia tronu był jednak krokiem wstecz, a nie naprzód.

I. Kant zalicza do drugiego artykułu również wynajmowanie oddziałów wojskowych jednego państwa innemu. W czasach filozofa,

12 Tajny protokót do paktu o nieagresji między Niemcami a Zwiazkiem Radzieckim, 23.08.1939 r. Cyt. za.: A. Radziwiłł, W. Roszkowski, Historia 1871 - 1939, Warszawa 2002.

${ }^{13}$ I. Kant, O porzekadle... Do wiecznego pokoju, dz. cyt., s. 50.

${ }^{14}$ Konstytucja 3-go Maja z 1791 r., rozdział 7. 
praktyki te były bardzo popularne wśród władców małych księstewek. Sądzę, że można by znaleźć podobne przykłady we współczesnym świecie, ponieważ użyczanie oddziałów wiąże się z korzyściami materialnymi (moc pieniądza jest bowiem największa spośród mocy sojuszy i mocy oręża, jak zauważył Kant ${ }^{15}$. Proceder taki, jeśli obecnie ma miejsce, na pewno nie jest jawny, ponieważ wiąże się z potępieniem na forum międzynarodowym i skutkami dyplomatycznymi. Przykładem tego może być fakt, że wiele państw fundowało działania i wspierało swymi oddziałami stronę palestyńską w konflikcie palestyńskoizraelskim. Podejrzewano o to m.in. Afganistan i Irak. Sądzę, że ważne jest, iż ten proceder nie ma poparcia ze strony międzynarodowego prawa i często jest ograniczany.

Trzeci artykuł preliminarny tzn. „wojska regularne (miles perpetuus) winny być z czasem zupełnie zniesione"16 wydaje się niemożliwym do spełnienia, chociaż uzasadnienie Kanta przemawia do zdrowego rozsądku. Istnienie wojska jest zawsze związane z możliwością jego użycia, a to z kolei wymusza możliwość obrony również poprzez posiadanie wojska. Tym sposobem, jeśli jedno państwo uzbroi się, wtedy wszystkie inne też powinny to uczynić, aby zapewnić sobie możliwość ochrony. Pozbycie się wojska przez jedno państwo nie gwarantuje rozbrajania pozostałych. Co więcej, powstaje wtedy niebezpieczeństwo, że wszystkie inne wykorzystają tą sytuację napadając na nie i rabując co się da. Możliwość zniesienia wszelkich wojsk umożliwiłby zakładany w drugim artykule definitywnym federalizm wolnych państw, które stały by się gwarantami pokoju.

W świecie wkraczającym w XXI wiek ciężko sobie wyobrazić brak wojsk. Istnieje wiele państw, które szanują ideę pokoju i których postawa w konsekwencji dopuszcza zniesienie wojska w przyszłości. Jednak istnieje mnóstwo państw czy to afrykańskich, czy azjatyckich, które swoje znaczenie zbudowały na wojsku lub w których rządzący utrzymuja się przy władzy dzięki armii. W takiej sytuacji wojska państw wyżej rozwiniętych ekonomicznie np. Stanów Zjednoczonych Ameryki Północnej czy organizacji np. NATO, staja się groźba, która wymusza poszanowanie praw. Zniknięcie tego zagrożenia otworzyłoby drogę do najgorszych zbrodnii. Realność tego założenia wydaje się znikoma. Istnieja państwa, które zniosły lub ograniczyły wojska. Państwem nie posiadającym sił zbrojnych jest np. Islandia, która ma obecnie tylko straż przybrzeżna. Było to możliwe dzięki gwarancjom silnych państw

\footnotetext{
${ }^{15}$ I. Kant, O porzekadle... Do wiecznego pokoju, dz. cyt., s. 51
}

16 Tamże. 
europejskich oraz Stanów Zjednoczonych - atak na Islandię, która nie posiada wojsk, oznaczałby atak na sojuszników NATO. Państwem o ograniczonych siłach zbrojnych jest Szwajcaria, która posiada wąską grupę wykształconych oficerów. Natomiast społeczeństwo szwajcarskie jest przeszkolone w zakresie obrony kraju - jest to tak zwana służba cywilna.

W kolejnym artykule preliminarnym jest mowa o tym, że „w związku z zewnętrznymi zatargami państwa nie powinny być zaciagane żadne

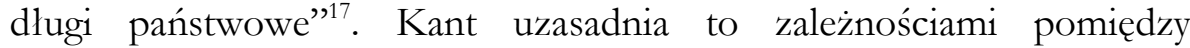
systemem kredytowym a możliwością prowadzenia wojen: kto posiada odpowiednie środki, a takowe może zdobyć właśnie dzięki kredytom zaciaganym u innych państw, może też prowadzić kosztowną i długotrwałą wojnę tak długo, jak długo starczy pożyczonych pieniędzy. Jest to niekorzystne rozwiązanie z punktu widzenia światowego pokoju, ponieważ nie dość, że kredyty pozwalaja prowadzić wojnę, to jeszcze często ich spłaty przyczyniaja się do ruiny kraju i uniemożliwiaja przerwanie działań wojennych, jako metody zdobywania pieniędzy. Jednak należy zauważyć, że zaciaganie kredytów na słuszne cele nie jest naganne - nie można się dziwić kredytom na budowę dróg, ulepszenie systemu oświaty itp.

Współcześnie bardzo często zaciagane są kredyty np. w Banku Światowym, przeważnie jednak na odbudowę kraju lub spłatę starych kredytów. Przykładem może być Polska, która posiada obciążające ja kredyty z czasów rządów komunistów, a zwłaszcza E. Gierka, które do dziś musi spłacać. Większość krajów posiada dług wobec innych państw - można powiedzieć, że nie ma obecnie państwa, które nie byłoby winne pieniędzy innemu. Z kredytami na prowadzenie wojny sprawa ma się nieco inaczej. Współcześnie kredyty na wojnę nie istnieja - w ramach organizacji międzynarodowych uzyskiwane jest wprawdzie wsparcie w czasie prowadzenia wojny, ale w postaci sprzętu i ludzi. W taki sposób współcześnie Polska uczestniczy w akcji w Iraku - służąc swoim sprzętem i polskimi żołnierzami, oczywiście nie bez widoków na korzyści płynące z tej współpracy.

Piąty artykuł preliminarny, który w Polsce wzbudził najwięcej emocji, stwierdza, że ,żadne państwo nie powinno mieszać się przemocą do ustroju i rządów innego państwa"18. Żadne bezprawie mające miejsce w kraju nie jest w stanie uzasadnić interwencji drugiego państwa w wewnętrzne sprawy tego pierwszego, ponieważ państwo wypełnione

17 Tamże, s. 52.

18 Tamże. 
przez chaos jest przykładem i ostrzeżeniem dla innych narodów. Nie wolno ingerować $\mathrm{w}$ jego sprawy wewnętrzne, lecz pozwolić mu samodzielnie rozwiązać wszelkie konflikty.

We współczesnym świecie debaty na temat tego, czy państwo bezprawne i pogrążone w chaosie należy ratować czy też czekać, aż samo zlikwiduje przyczyny kryzysu, należą do najbardziej zaciętych. Przykładem tego jest, mająca miejsce niedawno, dyskusja nad interwencja w Iraku prowadzona pomiędzy Stanami Zjednoczonymi Ameryki Północnej a europejskimi państwami, głównie Francją i Niemcami. Prezydent USA George Bush podkreślał, że interwencja w Iraku jest niezbędna. Jej uzasadnieniem miała być produkcja broni masowego rażenia przez Irak, jednak do dzisiejszego dnia nie znaleziono tam żadnej takiej broni. Różnica jest zasadnicza z punktu widzenia projektu Kanta jeśli siły zbrojne Stanów Zjednoczonych wkroczyły do państwa irackiego po to, by zapobiec łamaniu konwencji dotyczących produkowania, przechowywania i wykorzystywania broni masowego rażenia oraz zapobiec zagrożeniu międzynarodowego porządku, to wtedy byłaby to decyzja usprawiedliwiona. Jeśli jednak celem było obalenie dyktatora, to wtedy nie można mówić o słuszności tej wojny, gdyż łamie ona jeden z artykułów niezbędnych do wprowadzenia wiecznego pokoju.

Ostatni z artykułów preliminarnych jest poświęcony sztuce prowadzenia wojny. Mówi on, że „żadne państwo w stanie wojny z innym państwem nie może sobie pozwolić na takie wrogie kroki, które musiałyby uniemożliwić wzajemne zaufanie w przyszłym pokoju, jak: wynajmowanie skrytobójców, trucicieli, łamanie warunków kapitulacji, nakłanianie do zdrady w kraju, z którym prowadzi się wojnę "19. Nawet wojnę, której celem jest szybkie zwycięstwo należy prowadzić zgodnie z ogólnie przyjętymi zasadami moralnymi. Działania wymienione w cytowanym artykule podkopuja zaufanie stron do siebie nawzajem i uniemożliwiaja zawarcie pokoju. Współcześnie nie stosuje się już takich metod - większe pole do nadużyć pozostawia raczej użycie broni. Istnieją szczegółowe konwencje, które określają, których broni nie wolno stosować, co więcej, nakazują również jej zniszczenie i zaprzestanie produkcji. Taką bronia jest np. użyta po raz pierwszy przez USA podczas ataku na Hiroszimę (06.08.1945) oraz Nagasaki (09.08.1945) broń atomowa. Obecnie obowiązuje w stosunku do niej zakaz rozprzestrzeniania ustanowiony w $1968 \mathrm{r}$. Inną bronią masowego rażenia jest broń B, czyli bakteriologiczna. Działanie broni bakteriologicznej, opierającej się na dostarczeniu na teren przeciwnika chorobotwórczych

19 Tamże, s. 53. 
Idea ,wiecznego pokoju” Kanta... 181

mikroorganizmów, a także toksyn oraz zawiesiny zwanej aerozolem biologicznym, jest surowo zabronione konwencja podpisana 10.04.1972 r. w Nowym Jorku. Kolejną objętą zakazem bronią jest broń chemiczna, będąca najstarszym znanym rodzajem broni masowego rażenia. Masowo użyły jej po wojska niemieckie pod Ypres (22.04.1915), jednak już Chińczycy do pokonywania swych przeciwników używali środków chemicznych. Konferencja paryska z 1993 r podpisana przez 127 państw ustanowiła konwencję o zakazie prowadzenia badań, produkcji, składowania i użycia broni chemicznej oraz o zniszczeniu jej zapasów. Konwencje haskie z 1899 r., 1904 r. oraz 1954 r. określaja zasady prowadzenia wojny i traktowania jeńców - miało to zapobiec łamaniu praw człowieka i zbrodniom ze strony agresora.

Wszystkie te konwencje powinny napawać optymizmem, jeśli chodzi o prowadzenie wojny w najbardziej moralny sposób z możliwych, jednak należy zdawać sobie sprawę, że istnieja państwa, które nie podpisały tych konwencji, a nawet jeśli podpisały, to wciąż posiadają taką broń. III Rzesza prowadziła wojnę już po ustanowieniu dwóch konwencji genewskich, a jednak nie traktowała jeńców w odpowiedni sposób.

W drugim rozdziale „Do wiecznego pokoju” zawarto trzy artykuły definitywne, które jak sama nazwa wskazuje mają rozstrzygające znaczenie, jeśli chodzi o projekt. Podejmowany jest w nich publicznoprawny aspekt projektu o wiecznym pokoju. I o ile artykuły preliminarne są według R. Brandta adresowane do możnych władców, polityków i książąt, o tyle artykuły definitywne są raczej spojrzeniem na systemy polityczne z perspektywy ogólnej.

W pierwszym z nich Kant stwierdza, że „ustrój obywatelski w każdym państwie powinien być republikański" ${ }^{20}$. Uzasadnia to faktem, że w ustroju tym do wypowiedzenia wojny niezbędna jest zgoda wszystkich obywateli, a ponieważ są oni świadomi ciężarów, jakie nałoży im ona na barki, więc głęboko się zastanowią zanim wyrażą swoją zgodę. Jest to swoiste zabezpieczenie, jakie ustrój republikański nakłada sam na siebie. Zupełnie inna sytuacja ma miejsce w przypadku ustroju despotycznego, gdzie władza ustawodawcza i wykonawcza skupione są w jednym ręku. Osoba monarchy może bez najmniejszej szkody dla siebie zadecydować o wojnie, wysyłając po prostu swych poddanych na pole bitwy, a nie tracąc przy tym „swych uczt, polowań, rezydencji letnich, uroczystości dworskich"21. Ustroju republikańskiego nie należy utożsamiać z ustrojem demokratycznym. Demokracja w rozumieniu Kanta jest despotyzmem,

20 Tamże, s. 56.

${ }^{21}$ Tamże, s. 58. 
ponieważ większość może zdecydować o użyciu przemocy w stosunku do jednego, który nie będzie się z nimi zgadzać.

W pewnym sensie obawy Kanta sa uzasadnione, jednak demokracja współczesna nie wyklucza praw jednostek do własnego zdania. Prawa obywatelskie, dotyczace każdego, o ile nie został on tych praw pozbawiony, zapisane w konstytucjach, sa takie same dla wszystkich. Odmienne zdanie nie może być powodem pozbawienia zdrowia czy życia. Przykładem może być choćby polska Konstytucja z 1997 r., w której możemy przeczytać, że „wszyscy są wobec prawa równi” oraz „wszyscy maja prawo do równego traktowania przez władze publiczne" ${ }^{, 22}$.

„Prawo międzynarodowe powinno opierać się na federalizmie wolnych państw" ${ }^{\prime 23}$ czytamy w drugim artykule definitywnym. Nie ma innego rozwiązania, by móc zachować wieczny pokój pomiędzy państwami, ponieważ każda inna forma współpracy między państwami albo ogranicza prawa narodów do samostanowienia, albo nie ma w niej miejsca na pokój, ze względu na złe skłonności ludzkiej natury. Państwa dochodzą swych praw nie procesami, lecz wojna - jednak zwycięstwo tak naprawdę nie rozstrzyga o tym, kto ma rację, lecz mówi, kto dysponuje lepszymi wojskami itp. Bez porozumienia pomiędzy narodami nie da się zatem ustanowić pokoju. Najlepszym rozwiązaniem byłby związek pokojowy (foedus pacificum), który miałby za zadanie zakończyć wszelkie wojny.

Kant pisał, że „wykonalność (realność obiektywna) tej idei federacji (...) daje się wyobrazić" ${ }^{24}$ i nie pomylił się. Obecnie istnieja związki, które stawiają sobie za cel pokojową współpracę pomiędzy stronami i rozwój w warunkach zabezpieczonej wolności. Jednym z takich związków jest Unia Europejska, która mając różne cele, jak np. ochrona kultury i dorobku poszczególnych państw, współpraca na polu gospodarczym, realizuje cechy federacji wolnych państw, o jakich mówi Kant. Ciężko sobie wyobrazić sytuację, w której dwóch z członków Unii wypowiada sobie wojnę. Wszelkie konflikty rozwiązywane są dyplomatycznie. Co więcej, organizacja ta nie jest zamknięta struktura, lecz otwiera się dla wszystkich tych, którzy chcieliby współpracować (i, jak na razie, państwo członkowskie musi leżeć w Europie), tak więc realizuje założenie Kanta dotyczące zbawiennego wpływu ośrodka zjednoczenia, wokół którego skupia się inne państwa. Jest to jedyny takiego typu związek we

${ }^{22}$ Konstytucja RP z 1997 r., art. 32, pkt. 1.

${ }^{23}$ I. Kant, O porzeleadle... Do wiecznego pokoju, dz. cyt., s. 61.

${ }^{24}$ Tamże, s. 63. 
współczesnym świecie, wszystkie inne maja na celu albo tylko współpracę gospodarcza (co też jest korzystne, gdyż wojna nie sprzyja handlowi) albo ochronę przed agresorem.

W trzecim artykule mowa jest o tym, że „ogólnoświatowe prawo obywatelskie, powinno być ograniczone do warunków powszechnej gościnności" ${ }^{25}$. Nie chodzi tu o przesadną troskę i zbytnie zajmowanie się przybyszem, lecz o to, by nie był on traktowany wrogo tylko dlatego, że znalazł się na terytorium obcego państwa. Jest to warunek pozornie tylko łatwy do spełnienia. Wiele cudzoziemców, którym nie odmówiono prawa do przebywania na terytorium, wykorzystało to prawo aż nadto. Mam tu na myśli m.in. kolonizatorów. Często zdarzało się też, że ktoś zniknął po wjeździe do państwa albo go uwięziono.

Obecnie podróżnik, może się czuć o wiele bezpieczniej w czasie swych podróży. Nie ma prawa, które pozwalałoby na ograniczenie jego wolności, o ile nie popełnił on przestępstwa. Prawo gościnności jest zagwarantowane w różnych traktatach, konwencjach i układach. Można zatem powiedzieć, że sytuacja podróżnika w stosunku do sytuacji z czasów filozofa poprawiła się o wiele. Jednak nawet dziś zdarzają się nieprzyjemne sytuacje na tym polu np. wydalenie z Moskwy polskich biskupów jadących na konferencję bez podania jakiejkolwiek przyczyny.

Do wiecznego pokoju jest skonstruowane tak, jak prawdziwy układ pokojowy pomiędzy państwami. Jest to oczywiście podobieństwo nieprzypadkowe. Na końcu zasadniczego tekstu znajdują się dwa dopiski, z czego jeden opatrzony tytułem ,tajny”.

W pierwszym $z$ nich przedstawiona zostaje gwarancja wiecznego pokoju. Poręczenie to daje nam natura, której celem, podobnie jak rozumu, jest pokój. Jak stwierdza R. Brandt, „nasza powinność nie jest czymś chimerycznym, lecz wykonalnym, ponieważ jest zgodna z celami natury" 26 . Co więcej, przyroda gwarantuje zrealizowanie celu jakim jest wieczny pokój, ponieważ ona sama go realizuje, czyniąc to niezależnie od naszej woli w myśl fata volentem ducunt, nolentem trabunt ${ }^{27}$. Jest to pewnego rodzaju ostrzeżenie, aby postępować zgodnie z celem natury, a nie przeciwstawiać się mu, ponieważ natura zrealizuje swe cele niezależnie od naszej na to zgody. Można więc zadać pytanie, skoro natura i tak zrealizuje wieczny pokój, to czy trzeba cokolwiek robić w związku z tym?

\footnotetext{
25 Tamże, s. 65.

${ }^{26}$ R. Brandt, Uwagi historyczne i krytyczne na temat tekstu Kanta >Do wiecznego pokoju<, w: I. Kant, Projekt wiecznego pokoju, pod red. J. Garewicza, B. Markiewicz, Warszawa 1995.

27 „Przeznaczenie prowadzi chcącego, przeciwstawiającego się ciagnie za sobą”. Seneka, Epistola moralis, XVIII 4. Cyt. za.: I. Kant, O porzekadle... Do wiecznego pokoju, dz. cyt., s. 104.
} 
Wydaje mi się, że z punktu widzenia ludzkości, korzystniejsze jest szybkie osiagnięcie pokoju po to, by móc np. rozwijać handel. Pokój sprzyja rozwojowi wszystkich sfer życia - kulturalnej, naukowej, społecznej, jest zatem w interesie ludzi.

Drugi, tajny artykuł zawiera w sobie postulaty, które ogólnie określić możemy jako regulacje dotyczące wolności słowa, a zawarte są one w stwierdzeniu: „zasady filozofów o warunkach możliwości powszechnego pokoju powinny być rozważone przez państwa, zbrojące się do wojny"28. Tego rodzaju wolność wypowiedzenia zdania czy skrytykowania posunięć władzy, umożliwia właściwe spojrzenie na politykę wojenną państwa. Jak pisze Shaftesbury ,jedynym niebezpieczeństwem jest ustanowienie embarga. Zdarzają się wówczas takie same rzeczy, jak w przypadku handlu"29. Wolność słowa, czyli zapraszanie filozofów do współpracy, przyrównana zostaje do wolności gospodarczej, a obydwie te wolności sprzyjają pokojowi. Nie można jednak oczekiwać od filozofów takiej pozycji, jaką chciał im przypisać Platon - wpływ filozofów na władzę jest taki, na ile pozwoli im się publicznie wygłaszać poglądy, nic więcej.

Te trzy artykuły określają bardzo ogólnie, choć jednak oddając główną myśl, prawo, jakie powinno obowiązywać w państwie (Staatsrecht), między państwami (Völkerrecht) i kosmopolityczne (Weltbürgerrecht).

Czy w kontekście współczesnych wydarzeń międzynarodowych można mówić o realności wypełnienia postulatów zawartych w Do wiecżnego pokoju Kanta? Odpowiedź nie jest jednoznaczna.

$\mathrm{Z}$ jednej strony jest to możliwe, ponieważ w dzisiejszych czasach postulaty te wydaja się mniej chimeryczne niż w czasach filozofa państwa dążą do tego, aby czuć się na świecie bezpiecznie, a mając to na celu, mniej lub bardziej realizuja nakazy i zakazy zawarte w rozprawce. Obecnie świat jest oplątany siecią wielu sojuszy, które zapewniają czasowy pokój. Podejmuje się działania, które zmierzaja do pełnej ochrony praw człowieka i obywatela. Z drugiej strony pokój uzyskuje współcześnie inne znaczenie, ponieważ coraz częściej przydarzają się ataki terrorystyczne i zamachy.

Odpowiedź na pytanie może być również negatywna. Do wiecznego pokoju nigdy nie miało być realnym przepisem na wieczny pokój. Zadaniem filozofa powinno być pisanie o tym, jak powinno być, a nie

\footnotetext{
${ }^{28}$ I. Kant, O porzekadle... Do wiecznego pokoju, dz. cyt., s. 76.

29 Anthony Earl of Shaftesbury, Characteristics of Man, Manners, Opinions, Times etc, Glocester 1993, s. 46-47. Cyt. za: R. Brandt, dz. cyt., s. 101.
} 
Idea ,wiecznego pokoju” Kanta... 185

opisywanie tego, co zastał, gdyż to należy do historyka albo kronikarza. Kant postępując w myśl tej zasady, napisał coś, co jest teoretycznym projektem, który jednak niezupełnie odpowiada rzeczywistości. Jednak taki właśnie miał być. Jak pisze w ostatnich słowach Do wiecænego pokoju: „jeśli istnieje obowiązek, a równocześnie uzasadniona nadzieja urzeczywistnienia stanu powszechnego prawa, choćby tylko w nieskończonym przybliżaniu się do niego, to wieczny pokój (...) nie jest pustą ideą, lecz zadaniem, rozwiązanie którego następuje stopniowo (...) i które nieprzerwanie zbliża się do swego celu"30. Jeśli właśnie przez taki pryzmat będziemy postrzegać wieczny pokój, jako ciąłe zbliżanie się do idealnego stanu, to choćby ze względu na poprawę, która powinna nastąpić w czasie dążeń, warto jest próbować na tyle, na ile to możliwe wprowadzić kantowskie zasady w życie.

30 Tamże, s. 96. 